\title{
INDETERMINATE CONTROL OF OFFENDERS UNDER THE YOUTH CORRECTION AUTHORITY ACT: CONSTITUTIONAL ISSUES
}

\author{
Carney W. Mimms, JR.*
}

Section 12 of the Youth Correction Authority Act ${ }^{1}$ directs commitment to the Authority of persons, under 2I years of age when apprehended, who have been convicted of violations of law for which a lesser punishment than a mandatory sentence of death or life imprisonment ${ }^{2}$ is provided, but a greater punishment than the payment of a fine is permitted. Any person committed to the Authority is to be retained in its control "so long as in its judgment such control is necessary for the protection of the public,"3 and the Authority is directed to discharge the offender "as soon as in its opinion there is reasonable probability that he can be given full liberty without danger to the public."4

This discretion as to retention and discharge is subject to limitations. Certain periods of time are prescribed at the end of which control must terminate unless an order for an extension of control is confirmed in proceedings described in the paragraph following. Thus, control is to terminate when the offender attains age 21 or three years from the date of commitment, whichever is later, provided he either (a) was convicted of a minor offense punishable by a fine or not over $3^{0}$ days' imprisonment and was committed to the Authority because of previous violations of law, or (b) was 16 or 17 years old when committed to the Authority by a juvenile court. $^{5}$ Every other person committed to the Authority is to be discharged from its control before he attains the age of 25 years. ${ }^{6}$

The mandate to discharge is subject to an important exception in a provision that the Authority may order any person to remain subject to its control "for a longer period" whenever, in its opinion, discharge at the age or time limits previously stated would be "dangerous to the public."7 The Authority must apply to the appropriate court for a hearing to review its order. The Act then provides that

- LL.B., 1942, Duke University School of Law. Now in United States Navy Training School, University of Arizona. Member of Editorial Board, Duke Bar Association Journal, I941-42.

2 Youth Correction Authority Act (A. L. I., Official Draft, i940).

${ }^{2}$ Commitment to the Authority is discretionary with the judge when the offender could be sentenced to imprisonment for a period less than life, even though he could be sentenced to death or imprisonment for life.

Id. $\$ 29(2)$.
Id. $\$ 32(I)$.

${ }^{3}$ Y. C. A. Act, $\$ 29(I)$.

${ }^{5} I d . \$_{32}(2)$.

${ }^{7}$ Id. $\$ 33$. 
if after a full hearing the Court is of opinion that discharge of the person to whom the order applies would be dangerous to the public because of his mental or physical deficiency, disorder, or abnormality, or because of his lack of improvement under corrective training and treatment, the Court shall confirm the order of the Authority. If the Court is of opinion that discharge of the person from continued control of the Authority would not be dangerous to the public, the Court shall order the person to be discharged from its control. ${ }^{8}$

When an order of the Authority is confirmed by the court, the Authority's control over the offender continues (a) for 2 years in the case of offenders whose original commitments terminate at age $2 x$ or after 3 years, and (b) for 5 years in the case of other offenders. ${ }^{\ominus}$ At the end of the extended period, the Authority may make a new order and a new application for its review. The orders and applications may be repeated at the end of each 2- or 5-year period as many times as the Authority may deem necessary for the protection of the public. ${ }^{10}$

In actuality, therefore, the YCA Act provides for an absolutely indeterminate sentence. The automatic termination provisions are inoperative where the Authority can satisfy a reviewing court that the discharge of a person would be "dangerous to the public." And, as has been seen, the Act provides no minimum period of control. ${ }^{11}$

Clearly, these provisions are in line with the penal philosophy that an offender is a personality to be analyzed and treated and that the purpose of any period of control to which any offender is to be subjected is correction and rehabilitation rather than punishment. The YCA Act was drafted on the principle that the degree of supervision should be based on the character and personality of the offender rather than the nature of his offense. If the traditional penal theory that punishment and the fear it inspires is an effective crime deterrent is to be discarded in favor of the belief that, through clinical observation and individualized treatment, a convicted criminal may be equipped to resist the impulses likely to cause wrongdoing, the proponents of this Act argue that the period of confinement should be that necessary to effect his social rehabilitation, however long or short such period may be.

As is often true when social policies conflict, the answers to the constitutional questions raised by the YCA Act will ultimately depend on the penal philosophy of the various tribunals to whom those questions are presented. ${ }^{12}$ The risk of unreasonable discrimination and administrative abuse which an indeterminate sentence law permits has been feared by the courts and by the legal profession generally, although the philosophy which generates such a law is recognized as sound by the great majority of those concerned with criminal law and criminology. In the past the fear of administrative abuse has taken form in certain legal objections, and many of these would undoubtedly be raised with renewed intensity against a YCA Act, before both legislatures and courts. Therefore, it is important to examine the legal obstacles

\footnotetext{
${ }^{8} I d . \$_{34}(2)$.

Id. $\$ 35(1)$.

${ }^{10}$ Ibid.

11 Every offender shall be discharged as soon as in the opinion of the Authority "there is reasonable probability that he can be given full liberty without danger to the public." Y. C. A. Act, \$29(2). The lack of a minimum limit on the term of commitment seems to present no serious constitutional questions.

${ }^{12}$ See Long, Punishment v. Treatment in the Cure of the Criminal (1937) 2 JoHN Marstul. L. Q. 560.
} 
which this act must surmount to become a part of the American system of criminal justice.

A truly indeterminate sentence law stands as an origiral proposition today. There seems never to have been such a statute in our legislative history. The only state which to date has modeled a law on the YCA Act is California, and there constitutional doubts led to the excision of the indeterminate sentence feature of the YCA Act. ${ }^{13}$ Hence it is necessary to turn for constitutional authority to decisions dealing with other statutes.

\section{The Minimum-Maximum Sentence Laws as Analogues}

The most common form of indeterminate sentence which has been tested in the courts is based on the indeterminate sentence or parole laws in force today in 39 states. $^{14}$ However, the sentences they authorize are not truly indeterminate for the reason that both minimum and maximum periods of confinement are fixed by statute, or are judicially implied therefrom. Procedurally, these statutes usually follow the New York law enacted in 1877 for the Elmira Reformatory. ${ }^{15}$ The offender is sentenced for an indefinite period within the statutory limits, and some authority, usually a parole board, is given the power to terminate the sentence at any time after the expiration of the minimum term but before the expiration of the maximum.

The principal constitutional objections raised against these indeterminate sentence and parole laws have characterized them either as incompatible with the constitutional distribution of governmental powers or as interferences with the constitutional privileges of the individual offender. ${ }^{16}$ On the first score are four objections: (I) that an indeterminate sentence, with power in a board to release on parole, impairs the judicial power vested by the state constitution in the courts; (2) that to authorize a board to grant paroles infringes the pardoning power of the governor; (3) that to give a sentencing or parole board power to fix the time of detention is a delegation of legislative power; and (4) that for one or all of the foregoing reasons an indeterminate sentence is not due process of law. From the standpoint of the offender, it has been claimed (5) that the right of trial by jury is interfered with and (6) that punishment is not proportioned to the nature of the offense (a requirement found in a number of state constitutions); but the chief objection has been (7) that the indeterminate sentence renders the punishment so uncertain as to fall within the consti tutional inhibition of the cruel and unusual.

As applied to statutes prescribing definite minima and maxima, these objections have generally been held not to be well founded, and doubts whether parole and the indeterminate sentence thus limited are constitutional need no longer be entertained.

${ }^{13}$ The California statute limits the period for which control may be extended to the maximum provided by law for the offensc. Calif. Welfare \& INst. Cone (Deering, 1941) \$\$1700-I783.

${ }^{14}$ For a summary of the state systems, see Beattie \& Tolman, State Sentencing Practices and Penal Systems, Report to the Judicial. Conference of the Committee on Punishaient for Crime (i942) $8 \mathrm{I}$. See also I Atr'y Gen. Survey of Release Procedures (1938).

${ }^{16}$ N. Y. Laws 1877 , c. 173 .

${ }^{10}$ See Lindsey, Historical Sketch of the Indeterminate Sentence and Parole System (1925) I6 J. of Crim. L. \& Criminol. 9. 
There is considerable variation in the provisions of the various statutes, but the decisions and the reasons given for them are much more uniform. These will now be considered and their applicability to the YCA Act discussed briefly. In this discussion, it will be assumed that the courts will treat the YCA Act as imposing criminal punishment.

(I) The objection that these minimum-maximum sentence statutes impair the judicial power has been denied on the ground that it is among the admitted legislative powers to define crimes and to fix the period and manner of punishment. Thus the legislature may fix a definite sentence for each crime without infringing the judicial power. It may also give the courts discretion to fix the sentence between certain limits; but, as this right is given to the courts by the legislature, so it can be taken away. ${ }^{17}$ Nonetheless, the objection that an indeterminate sentence law impairs judicial authority is a live issue today. A bill to provide a Federal Indeterminate Sentence Law, reported favorably by the House Judiciary Committee in $194 \mathrm{I},{ }^{18}$ encountered the vigorous opposition of federal district judges on the ground that it deprived the judiciary of its control over sentencing. ${ }^{10}$

Whatever the wisdom of the measure, it is difficult to see exactly what constitutional power the judiciary can lose under the operation of an indeterminate sentence law. Where the legislature exerts its power to fix the exact penalty for a crime, the judicial function is solely that of pronouncing the predetermined sentence. Where the legislature gives the jury power to fix the sentence, ${ }^{20}$ again the judiciary is left to exercise no discretion. A direction that the trial judge should commit to a board or an authority, as under the YCA Act, seems to constitute no greater limitation. However, a practical explanation of judicial opposition to the true indeterminate sentence law is doubtless the fact that in most states the judiciary has actually been exercising considerable discretion in fixing periods of confinement ${ }^{21}$ and is reluctant to surrender this responsibility to an administrative board.

(2) The second objection, infringement of the governor's pardoning power, has been overruled on divergent grounds, depending on the particular provisions of the statute in question. Where a distinction between parole and pardon has been recognized, ${ }^{22}$ the parole board is looked upon as granting only a conditional release which allows the prisoner to serve the remainder of his sentence outside the penal institution, subject to re-imprisonment upon a breach of one or more conditions. Where parole

${ }^{17}$ Miller v. State, 549 Ind. 607,49 N. E. 894 ( 1898 ); State v. Duff, r44 Iowa 142,122 N. W. 829, 24 L. R. A. (N. S.) 625 (1908); State v. Peters, 43 Ohio St. 639,4 N. E. 8 I (1885).

${ }_{18}$ H. R. ReP. No. IO7I, on H. R. 4586, 77th Cong., Ist Sess. (1941).

${ }^{19}$ Report of the Sub-Committee on Sentencing of Adult Prisoners, Report to THe JudicinL Conperence of the Commiten on Punishment for Crime (1942) 5, 6. A questionnaire sent to federal district judges elicited 52 replies in opposition to the bill and to in favor of it.

${ }^{29}$ This delegation is valid. Pcople v. Illinois State Reformatory, 148 Ill. 413, 36 N. E. 76 (1894); Miller v. State, stupra note 17; Woods v. Tennessec, I39 Tenn. 100, 169 S. W. 558, L. R. A. 1915F 531 (19I4).

${ }^{21}$ Sce note 14 , supra. (1891).

${ }^{22}$ E.g., State v. Peters, supra note 17. Contra: People v. Cummings, 88 Mich. 249,50 N. W. 310 
has been held to be a conditional pardon, ${ }^{23}$ it could be constitutionally granted only by the governor, and therefore most statutes in such states, have provided that the parole board has only the power to recommend pardon for a prisoner, final discharge being granted by the governor. In states where the rule is uncertain, to avoid any difficulty, statutes often provide for the concurrence of the governor in the granting of parole or at least of a final discharge. ${ }^{24}$

Action under the YCA Act may include a release on condition or under a certain degree of supervision and control, but it may also include a complete discharge granted by the Authority alone. Obviously, the program envisaged in the YCA Act would be greatly hampered if the governor's concurrence in every final discharge were required. Against the argument that the powers vested in the Authority infringe the governor's pardoning power, it could be said that a pardon is not exclusive of other releases. That is, a pardon is a particular type of release limited by definition to executive clemency, and hence a board could grant a final discharge without infringing the pardoning power. Further, it might be argued that, where the Authority releases an offender, it is only delimiting the sentence as authorized by the Act; it is not cutting short a previously fixed sentence. Hence its release is not a pardon, conditional or otherwise.

(3) As to the objection that to confer powers upon a parole board is a delegation of legislative authority, it has been held that the legislature fixes the period of confinement at the maximum it provides for an offense and hence there is no attempt to confer on the board the power to fix the punishment that the crime should bear. ${ }^{25}$ The question of the extent to which discretionary power may be granted by statute to a parole board has not been given adequate treatment in any of the minimummaximum sentence cases. Where the question has been discussed, most cases have regarded the board's authority to grant parole and discharge and to establish rules therefor as calling merely for administrative action. ${ }^{26}$ This view would doubtless prevail as to action under a YCA Act within the period limited by the statutory termini. However, the question as to the effect of granting greater discretion than has been given the parole boards appears to be still open. ${ }^{27}$

The validity of a grant of discretionary power to any administrative agency is generally tested by the familiar inquiry as to the adequacy of the standard provided to guide the agency's action. With respect to the extension of control over offenders beyond the statutory termini, the YCA Act provides the legislative standard "danger-

\footnotetext{
${ }^{23}$ See, e.g., Prison Commissioners v. De Moss, 157 Ky. 289, 163 S. W. I83 (1914), which said that a statute providing for final discharge of a prisoner without concurrence of the governor would be unconstitutional.

${ }^{24}$ Such acts have generally been held to be merely regulative of punishment of prisoners and not as infringement on the pardoning power. George v. People, 167 Ill. 417,47 N. E. 741 (1897); Miller v. State, supra note 20; State v. Duff, supra note I7; State v. Page, 60 Kan. 664, 57 Pac. 514 (i899); Murphy v. Commissioners, I72 Mass. 264, 52 N. E. 505; Ex parte Marlow, 75 N. J. L. 400, 68 Atl. I7I (1907); People v. Adams, I76 N. Y. 35I, 68 N. E. 636 (1903); State ex rel. Greene v. Rimmer, 131 Tenn. $3 \times 6,174$ S. W. $x \times 34$ (xgr5).

${ }^{25}$ State v. Peters, supra note I7; Woods v. Tennessee, stipra note 20.

${ }^{20}$ Cases cited supra note 24.

${ }^{27}$ See Lindsey, supra note 16 , at 46.
} 
ous to the public," plus, inferentially, the more specific standards provided for the guidance of the reviewing court which are quoted above. These standards in the YCA Act would seem as definite as those found in many legislative grants of power to administrative bodies. The exercise of the Authority's power to extend control, moreover, is subject to judicial review and the offender is assured of a hearing. Yet the delegation in the YCA Act runs the hazard of close scrutiny and a peculiarly strict rule for the Act operates to affect individual freedom. Thus, at this point, the consideration of the individual offender's rights and privileges tends to merge with the consideration of governmental powers.

(4) The "due process of law" argument seems to have been offered by counsel for prisoners as a catch-all objection, but the courts have tended to narrow it to the question whether the parole statute violated the constitutional distribution of powers in delegating judicial and/or legislative power to an executive body. When this question was raised in the state courts, they sustained the statutes, ${ }^{28}$ and it was held by the United States Supreme Court not to be a federal question. ${ }^{29}$ The first ten amendments to the Federal Constitution limit the national government alone, and the Supreme Court has held the Fourteenth Amendment not to limit the powers of a state in dealing with crime committed within its borders, or with the punishment thereof, as long as the state does not deny to any person "equal and impartial justice under the law."30

(5) The basis for the objection that the right of trial by jury was interfered with lay in the fact that the jury had been directed in many states to fix the period of confinement within the statutory limits. It was held, however, that, as the assessing - of punishment by the jury was no part of the common law but rather rested entirely on modern statutes, this right could be taken away by statute without impairing any constitutional right. ${ }^{31}$ These decisions would seem sufficient precedent to uphold the YCA Act if it is objected to on this ground.

(6) State constitutional provisions that punishment shall be proportioned to the nature of the offense have been broadly construed. It has been held that the term of imprisonment, "if it does not extend to perpetual imprisonment, is to a great extent, if not altogether, a matter of legislative discretion."32 This statement suggests that, since there is a possibility under the YCA Act that confinement would extend to perpetual imprisonment, the Act would be held unconstitutional as going beyond the limits of allowable legislative discretion. Moreover, it could be argued that, unlike the minimum-maximum laws, the YCA Act employs standards wholly unrelated to the offense and depending wholly on the offender. These contentions are difficult to meet so long as the assumption that the Act provides punishment is adhered to. However, the difficulty relates primarily to the period of extended control; the prob-

\footnotetext{
${ }^{28}$ People ex rel. Bradley v. Illinois State Reformatory; Woods v. Tennessec, both supra note 20.

${ }^{20}$ Dreyer v. Illinois, $x 87$ U. S. 71 (I902).

${ }^{30}$ Ughbanks v. Armstrong, 208 U. S. 481,487 (1908).

${ }^{31}$ See note 20 , supra.

${ }^{32}$ People v. Illinois State Reformatory, I48 Ill. 4I3, 421, 36 N. E. 76,79 (1894).
} 
ability is great that the statutory termini would be viewed as having sufficient relation to the offenses of minors to render this portion of the Act clearly valid.

(7) One of the focal points of a constitutional attack on the YCA Act would doubtless be that the Act, specifying no terminus to control, authorizes sentences which are indefinite and hence invalid as being cruel and unusual punishment. ${ }^{33}$ When this objection was raised against the indeterminate sentence in the minimummaximum form, it was generally held that the sentence was not uncertain or indefinite because it was for the longest period specified by the legislature for the crime of which the prisoner was convicted. ${ }^{34}$ There is an implication that a completely indefinite or uncertain term would render the sentence unconstitutional. Whien raised against sentences under the YCA Act, that objection might be met by the defense that YCA commitment is no more subject to condemnation as a cruel and unusual punishment than are life sentences under the so-called "habitual offender" laws, which have existed as a valid part of our criminal law since $18 \mathrm{I}^{\prime} .^{35}$ Some of these statutes provide for life imprisonment of certain offenders without regard to the statutory penalty provided for the last crime committed. If "so inflexible a standard as that furnished by the ordinary habitual offender laws"36 is not cruel or unusual punishment, why should the mere risk of perpetual imprisonment which results from the absence in the YCA Act of any maximum limit raise so grave an issue? Of course, the fact that the habitual offender has committed several crimes of a serious nature does provide a definite and objective, if crude, basis for curtailing his freedom permanently. Against this ground of distinction would have to be weighed the protection accorded the offender under the YCA Act by periodic administrative reconsideration of his case, coupled with judicial review.

\section{Juvenile Court and "Defective Delinguent" Acts as Analogues}

A court which, on one or more of the grounds discussed above, persists in requiring maximum limits in a statute authorizing imprisonment as punishment for crime, might reach a contrary conclusion if it could be.persuaded that the YCA Act prescribed, not punishment, but corrective treatment. Any inquiry whether this differentiation can be established calls for the consideration of two analogous forms of control: (I) control of juvenile delinquents, and (2) control of "defective delinquents."

(I) The juvenile courts have operated outside the traditional boundaries of the

${ }^{33}$ U. S. Const., Amend. VIII, and state counterparts.

${ }^{34}$ People v. Joyce, 246 Ill. I24, 92 N. E. 607 (I910); Skelton v. State, I 49 Ind. 64,49 N. E. 901 (1898); State v. Perkins, I 43 Iowa 55, 120 N. W. 62, 2I L. R. A. (N. S.) 93I (1909); Ex parte Marlow, supra note 24; Pcople ex rel. Clark v. Warden of Sing Sing Prison, 39 Misc. 113, 78 N. Y. Supp. 907 (1902).

${ }^{35}$ Sce Sutherland, Principles of Crmmology (1934) 495. In I933 seven states prescribed a mandatory life sentence on conviction for a third felony and nine states provided a similar penalty on conviction of a fourth felony.

${ }^{30}$ Note (1937) 50 Harv. L. Rev. 677, 679: "It can hardly be maintained that potential criminality, which is a subjective problem of personality, may be better gauged by counting the number of objective offenses rather than by continued observation of the offender by psychiatrists and others trained to deal with the workings of mind and emotion." 
criminal law. Proceedings before the juvenile courts are held not to be criminal in character but partake more of civil proceedings in chancery. None of the constitutional safeguards peculiar to the trial of a criminal are assured the juvenile defendant because he is not being prosecuted criminally. ${ }^{37}$ When the juvenile court directs that a juvenile delinquent be subjected to control, that control is looked upon not as punishment for crime but as correction, administered by the state as parens patriae acting in loco parentis.

It is clear that the theories of the juvenile courts and of the YCA Act are closely related. However, there are at least two differences of significance in their operation. In the first place, the YCA Act contemplates the prosecution for crime of the youth offenders committed to it. It is not until commitment that the offender's case is to be differentiated from that of the adult criminal. This consideration raises the question whether the controls consequent upon conviction for crime can be regarded as other than punishment and therefore not subject to constitutional limitations on the imposition of punishment. There is some authority that this is permissible in the case of minors. Prior to the creation of juvenile courts, statutes directed the commitment of minors convicted of crime to reformatories for the period of their minority unless sooner released by the reformatory administrators. This control was considered a valid exercise of the state's power as parens patriae. ${ }^{38}$

These cases give strong support to the Authority's discretion in the period preceding the automatic termination of control. It is less likely that the continued control of the offender, long after he has become an adult, will be so regarded. Yet, as has been seen, it is this very power to extend controls indefinitely that gives rise to the chief constitutional diffculty. It is here, however, that aid may be found in the "defective delinquent" acts.

(2) The "defective delinquent" type of statute is a far less familiar phenomenon than the juvenile court act and, accordingly, some description of these laws is indicated before their bearing upon the YCA Act is considered. It is, of course, thoroughly established that, in the exercise of their police power, the states may restrain the liberty of afflicted individuals found dangerous to the health and safety of the people. Several states have enacted statutes providing that persons who, although not insane, have mental tendencies which render them dangerous to the public may be confined for an indefinite period, e.g., until they are no longer dangerous. The New York "Mental Deficiency Law"39 authorizes commitment to the institution for de-

${ }^{37}$ Sce Flexner and Oppenheimer, The Legal Aspect of the Juvenile Court, U. S. DEP'T of LABOR, Chrldren's Bureau Publ. No. 99 (xg22) 8. Among the leading cases are Ex parte Januszcwski, 196 Fcd. I23 (C. C. S. D. Ohio, IgII); Lindsay v. Lindsay, 257 Ill. 328, 100 N. E. 892 (I913); Wissenberg v. Bradley, 209 Iowa 8r3, 229 N. W. 205, 67 A. L. R. 1075 (r930); Commonwealth v. Fisher, 213 Pa. St. 48,62 Atl. $x 98$ (rg05). In People v. Lewis, 260 N. Y. 17I, 183 N. E. 353 (1932), the New York Court of Appeals warned that, while guaranties applying to criminal prosecutions are not assured, the charge against the offender must be definite and the rules of evidence customary in civil cases followed.

${ }^{38}$ Ex parte Liddell, 93 Calif. 633,29 Pac. 251 (1892), 3 A. L. R. I614 (1919); State ex rel. Schulman v. Phillips, 73 Minn. 77, 75 N. W. I029 (1898); State v. Cagle, III S. C. 548, 96 S. E. 291 (1918); cf. People ex rel. Bradley v. Illinois State Reformatory, stpra note 20.

${ }^{30}$ IOB N. Y. Consol. Laws (McKinney, Supp. 1942) art. 17, \$9430-448. Similar provision is made 
fective delinquents at Napanoch, of any "male mental defective over 16 years of age convicted of a criminal offense." Pennsylvania provides ${ }^{40}$ for commitment to a similar institution of any person over I5 $_{5}$ who has been "convicted of crime before any court, or is held as a juvenile delinquent" and has been found "mentally defective and [possessing] criminal tendencies, whether or not coupled with mental instability." Massachusetts has a very similar law $^{41}$ with a I6-year age limit and the additional requirement that, to allow indeterminate commitment as a defective delinquent on the first offense, it must appear to the court that the offender has a tendency to recidivism of a serious type. ${ }^{42}$ "Sex offender" or "sex deviate" statutes are found in two states, Illinois ${ }^{43}$ and Minnesota. ${ }^{44}$ These provide, in substance, for indefinite commitment to a proper institution of sex offenders who suffer from a mental disorder coupled with criminal propensities which render them dangerous to the public.

As in the case of the juvenile court acts, these defective delinquent and sex offender statutes are viewed primarily as providing for civil, and not criminal, proceedings. Moreover, the commitment they authorize is regarded as of the same nature as the indefinite commitment of insane persons. ${ }^{45}$ The "convicted" person is not "sentenced" for the crime he has perpetrated, and in legal theory the sole basis for placing him in an institution is his mental condition. That is, the fact that he has committed a crime is relevant only in that it may be the best indication that he has dangerous criminal tendencies. The statutes are not considered part of the criminal law but are deemed to have been enacted under the same authority by which a state maintains institutions for the feeble-minded, the aged and infirm, provides for compulsory vaccination, enacts quarantine regulations, and generally adopts such regulatory measures as are in the interest and for the protection of the public health and welfare.

This distinction is emphasized in the Illinois sex-psychopath law which does not make the conviction for a criminal offense a prerequisite to commitment. To accentuate the distinction between hospitalization for mental treatment and punishment for crime, the Illinois act provides that, after the sexual psychopath has been adjudged cured, he is to be remanded for trial for his criminal offense. The proceedings under this group of statutes are further likened to inquests for committing the insane by the fact that all the acts require thorough examination by scientists and a detailed report

in Article I7-A for the commitment of mentally defective delinquent women in an institution at Albion, N. $\mathrm{Y}$.

${ }^{\circ}$ Pa. Laws 1937, No. 808, 61 PA. Stat. Ann. (Purdon, Supp. 1942) c. 6A, $\$ \$ 54 \mathrm{I}-\mathrm{I}-54 \mathrm{I}-\mathrm{I0}$.

11 Mass. Gen. LAws (1930) c. 123, §130.

12 For a full discussion of these statutes and their operation, see Robinson, Institutions for Defective Delinquents, 24 J. Crim. Law \& Criminol. 352 (1933). A Michigan statute, Mich. Pub. Acts 1937, Act No. 175, of the same type was dechared unconstitutional in People v. Frontczak, 286 Mich. 5I, 28I N. W. 534 (1939), discussed below.

13 Ill. Laws 1938, Ist Spec. Sess., p. 28, Ilx. Stat. ANn. (Jones, Supp. I942) $\$ 37.665(1)-(6)$.

"Minn. Laws 1939, c. 369, MinN. Stat. (194r) \$\$526.09-529.Ir.

${ }^{15}$ See note (1939) 39 Cot. L. REv. 534, 540, discussing the Illinois act. 
finding that the person examined is mentally defective before commitment can be authorized. ${ }^{48}$

There is a close resemblance between the YCA Act provisions authorizing the Authority to order extensions of control and the provisions of the "defective delinquent" acts outlined above. However, in the commentary to the Official Draft of the YCA Act it is made clear that the Act was drafted on the theory that the court order continuing control is not in the nature of a new commitment "but only an approval of the Authority's action under the original commitment."'47

The practical importance of the distinction between an indeterminate commitment as the result of civil proceedings and as a result of criminal proceedings was brought out in the 5-to-3 decision in People v. Frontcza ${ }^{4}{ }^{48}$ which invalidated the recent Michigan "sex offender" act. The statute was very similar to the Illinois act, except that Michigan made conviction of a sex crime a prerequisite to commitment. The proceedings were separate from the criminal trial, being brought either before sentence or after commitment. The act was held invalid on the ground that it provided for a criminal proceeding without observing certain constitutional rights guaranteed to the accused in a criminal case, the main deprivation being the accused's right to trial by a jury of the vicinage. The majority described the statute as subjecting an accused to two trials and convictions in different courts for a single statutory crime. The opinion went on to say that if the two trials were not for a single statutory offense, then one trial was for a penalized overt act and the other for having a mental disorder, for which criminal procedure was not prescribed. Since, however, the act was an amendment to the criminal code, failure to prescribe criminal procedure violated the rule that the subject of a statute must be embraced by its title. The dissenters argued that, although the statute was germane to the criminal code, the proceedings under the act were solely in the nature of an inquest and did not constitute a criminal proceeding in the sense that the prisoner was subjected to a trial for a statutory crime.

By its insistence on the continuity of the extension proceedings with the criminal trial resulting in commitment, the Institute draft seems designed to escape the dilemma posed by the court in the Frontczak case. There is only one trial and it is for only one offense. However, this tactic diminishes the possibility of avoiding those attacks on the Act based on the theory that it is a criminal statute which is invalid by reason of the indefiniteness of the punishment it prescribes. This is unfortunate since, if the extension proceedings were viewed as distinct from the criminal, not only would the constitutional guaranties safeguarding criminal prosecution and punishment be inapplicable, but the Act could more readily draw for support on the one

\footnotetext{
${ }^{16}$ The New York statute, stupra note 39, requires 2 physicians or one physician and one psychologist; the Massachusetts act, supra note 4I, 2 physicians; the Pennsylvania act, supra note 40, 2 physicians or one psychiatrist.

${ }_{47}$ Y. C. A. Act (A. L. I. Official Draft, I940), pp. 40-4I.

${ }^{48} 286$ Mich. 51, 28r N. W. 534 (1939); criticized in (r939) 37 Mrar. L. Rev. 613.
} 
United States Supreme Court case sustaining a defective delinquent statute, Minnesota ex rel. Pearson v. Probate Court, ${ }^{49}$ decided in 1940.

The Minnesota act $^{50}$ there upheld authorized a proceeding instituted in the Probate Court by the county attorney which led to the indefinite commitment of the "patient" if he were found to have a "psychopathic personality," a term broadly defined by reference to the patient's instability and irresponsibility for "conduct with respect to sexual matters," rendering him "dangerous to other persons." The Minnesota Supreme Court construed the statute as intended to include only those persons who, though not insane, had evidenced, by an habitual course of misconduct in sexual matters, an utter lack of power to control their sexual impulses and who, as a result, were likely to attack or otherwise injure the objects of their uncontrolled and uncontrollable desire. ${ }^{51}$ In sustaining this act against attack as void for uncertainty, the United States Supreme Court emphasized the fact that it was bound to accept the state court's strict construction and declared: "This construction of the statute destroys the contention that it is too vague and indefinite. . . ."52

The standards of the Minnesota Act are not those of the YCA Act, and it becomes important to consider whether the degree of difference between them is such as to destroy the pertinence of Minnesota v. Probate Court as a precedent, if otherwise it is to be regarded as relevant. In this connection it is to be recalled that the ground upon which the Authority may exercise its authority to retain control over an offender indefinitely is stated in the alternative: continued control may be had when discharge of the person would be dangerous to the public, either (I) because of his' mental or physical deficiency, disorder, or abnormality, or (2) because of his lack of improvement under corrective training and treatment. ${ }^{53}$

The proponents of the YCA Act contend that the great majority of youthful offenders committed to the Authority would be released without need for retention beyond the age limits specified.54 Of the group for which indefinite control would be sought, it is believed that only a small percentage would be mentally defective or disordered. Statistics show that very few youth offenders are in this category. ${ }^{\mathbf{6 5}}$ The feeble-minded and the deranged would in all probability be placed in suitable institutions by the Authority, and indeterminate control for them based on appropriate laws for persons so afflicted.

10309 U. S. 270 (1940).

${ }^{\circ}$ Supra note 44 .

${ }^{61}$ State ex rel. Pearson v. Probate Court, 205 Minn. 545, 287 N. W. 297 (1939).

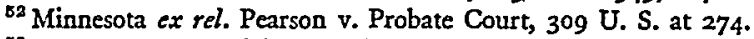

${ }^{63}$ Y. C. A. Act, $\$ 34(2)$, quoted at p. 636 , supra.

"Sec, e. g., J. R. Ellingston (Special Adviser, Criminal Justice-Youth, A. L. I.) A Broadside Attack on Crime (ms. I942): ". . . the Act provides machinery so that the few offenders who may prove incorrigible and a menace to safety may be indefinitely segregated."

E5 "Psychiatric studies conducted on approximately ro,000 convicted offenders reveal that Mental Defectives and Insane (psychotic) offenders constitute a small proportion of the whole $(2.4 \%$ and $x .5 \%$ respectively). Offenders diagnosed as Psychopathic Personality according to accepted Psychiatric criteria comprise $6.9 \%$ of the total." Bromberg \& Thompson, The Relation of Psychosis, Mental Defect, and Personality Types to Crime (1938) $28 \mathrm{~J}$. of CRIM. L. \& CrImINoL. 70, 87. A study of 4000 juvenile offenders revealed that $72.5 \%$ were definitely normal mentally; $13.5 \%$ were found to be clearly feebleminded, and $2.8 \%$ were psychopathic personalities. Heary \& Bronner, Delinquents and Crumanals (x926) $x_{49-152 .}$ 
That the YCA Act's concern is with criminality and not insanity is shown by the fact that the criterion of danger to the public under which indefinite control is authorized is based on mental abnormality as well as mental deficiency. Persons in the former class are usually referred to as "psychopathic personalities." This term is not limited, as in the Minnesota Act, to sex deviates; it applies generally to persons who, although possessed of good intelligence, are to be considered mentally abnormal (as opposed to mentally deficient) because of maladjustment, emotional instability, or other personality or character defects. ${ }^{56}$ It is in this group that a Youth Correction Authority would probably find the greatest number of cases for extension orders.

Although neither the medical nor legal authorities are by any means in accord as to the proper definition of "psychopathic personality," it is generally agreed that an anti-social life is not sufficient evidence that the individual is of psychopathic personality. ${ }^{57}$ That is, the fact that an offender is antagonistic to his fellowmen and shows tendencies to recidivism, does not of itself establish his mental abnormality. No state today makes special provision for the psychopathic personality group, ${ }^{58}$ except to the extent that sex offenders may be so regarded.

Uncertainty whether medical and psychiatric authorities have advanced far enough today to allow segregation and specialized treatment solely on the basis of subjective personality analysis revealing "mental abnormality" would doubtless be the principal source of constitutional difficulty for a court willing to regard extensions of control as continued treatment rather than as criminal punishment. Furthermore, a narrow construction of the legislative standard, which would nonetheless preserve the provision's chief objectives, is less easy to achieve than in the case of the Minnesota Act which by its terms was narrowed to the category of sex deviates.

If, however, extension of control over the mentally abnormal were sustained, there would still remain those individuals of normal intelligence who manifest such a tendency toward recidivism as to be dangerous if released. It is for this group that

${ }^{50}$ Dr. P. A. Draper, in his article, Mental Abnormality in Relation to Crime (1939) 2 AM. J. Or MED. JuRIs. I6I, I63, under the heading, "Those who are Mentally Ill but are still Responsible for their Crimes," defines "psychopathic personalities" as "individuals who show a lifelong and constitutional tendency not to conform to the customs of the group. They habitually misbehave. They have no sense of responsibility to their fellow-men or to society as a whole. Due to their inherent inability to follow any one occupation, they succumb readily to the temptation of getting easy money through a life of crime. There is usually a history of delinquency in early life. These individuals fail to learn by experience. They are inadequate, incompatible, and inefficient. . . . The term 'moral deficiency' is sometimes used to characterize this group."

${ }^{57}$ See Bromberg \& Thompson, supra note 55, at 75: "We do not assume that an anti-social life is sufficient evidence that the individual is of psychopathic personality. . . An antisocial attitude docs not necessarily mean that the individual is emotionally unstable, paranoid, or schizoid. Very often an antisocial individual cannot be distinguished by his appearance and ordinary behavior from those who occupy their regular place in the workaday world. To apply the term psychopathic personality because of 'criminal' activity, as is often done, affords no clue to the individual's reaction or the devclopment of this reaction, and assists us no more than any other derogatory label. The notion 'criminal' is a legal, not a psychiatric concept." (Italics supplied.) Sce also TAFT, Criminologr (1942) 85.

${ }^{8}$ That psychopathic offenders whose intelligence is average or above average are not to be treated as defective delinquents under New York law, sce Robinson, supra note 40 , at 335 . In Massachusetts, delinquents with a mental age of 12 ycars or over are not admitted to the institutions for defective delinquents. Id. at 37 I. However, New Jersey has defined defective delinquent administratively to include intelligent offenders of unstable personality. Id. at 373 . 
the provision of the Act authorizing indeterminate control of those offenders who have shown a lack of improvement under corrective training and treatment is designed. The criterion of "lack of improvement" must be considered in terms of behavior, since if the failure could be attributed to mental defect or abnormality there would be no occasion for this alternative ground of retention. Hence, it is difficult to gain support from the defective delinquent and sex offender statutes. The proceedings under this section could not readily be analogized to lunacy inquests, and instead would seem to stand or fall as being within the scope of the correction or punishment imposed for the original criminal offense.

\section{The Propriety of the Act's Classificatton and Procedure}

Whether control of offenders under the YCA Act is classed as an exercise of criminal or of civil powers, there will remain two further constitutional questions. The first of these is whether the limitations of the indeterminate-sentence feature to persons under $2 \mathrm{I}$ years of age at the time of their apprehension violates the "equal protection of the laws" clause of the Fourteenth Amendment. This clause does not prevent classification for the purpose of individual treatment so long as such classification is not unreasonable, arbitrary, or capricious, and is fairly designed to effect the purpose sought by the classification. ${ }^{59}$ In view of legislative freedom to recognize degrees of harm and confine its restrictions to those classes of cases where the need is deemed to be clearest, the classification of $I 6-2 I$ is not likely to be held unreasonable. The disproportionate ratio of criminals in this age group to the general population would be an important factor supporting the classification. ${ }^{00}$

A second, more serious question is whether administrative abuse of the powers conferred on the Authority by the YCA Act might not lead to a deprivation of liberty without due process of law or to a denial of the equal protection of the laws. The risk of such abuse will not invalidate the Act unless the Act fails to provide adequate procedural safeguards to the offender. The statute in providing for judicial review of extension orders, for a hearing, and for representation of the offender by counsel seems to comply with the principal criteria of procedural due process, though it does not specify, as do the defective delinquent acts, for the examination of the offender by physicians, psychiatrists, or psychologists. But failure to rest an order for extension on adequate evidence would be ground for refusal to confirm by the reviewing court, and that court's judgment could in turn be reviewed on appeal.

In the Minnesota case, various hazards of administrative abuse were called to the attention of the Supreme Court which responded by saying: ${ }^{81}$

${ }^{80}$ Minnesota ex rel. Pearson v. Probate Court, 309 U. S. 270 (I940).

so "Young people between fifteen and twenty-one years of age constitute only 13 per cent. of our population above fiftcen, but ... they are responsible for approximately 26 per cent. of our robberies and thefts; they constitute some 40 per cent. of our apprehended burglars and nearly half of our automobile thieves. . . I 108,857 not yet old enough to vote were arrested and fingerprinted last year [I939]". Introductory Explanation, Y. C. A. Act (A. L. I., Official Draft, I940), p. vii.

${ }^{21}$ Minnesota ex rel. Pearson v. Probate Court, 309 U. S. at 277. 
We fully recognize the danger of a deprivation of due process in proceedings [of the type there in question], and the special importance of maintaining the basic liberty in a class of cases where the law though "fair on its face and impartial in appearance" may be open to serious abuses in administration and courts may be imposed upon if the substantial rights of the persons charged are not adequately safeguarded at every stage of the proceed. ings. But we have no occasion to consider such abuses here, for none have occured. The applicable statutes are not patently defective in any vital respect, and we should not assume, in advance of a decision by the state court, that they should be construed so as to deprive appellant of due process to which he is entitled under the Federal Constitution. . . . On the contrary, we must assume that the Minnesota courts will protect appellant in every constitutional right he possesses. His procedural objections are premature.

\section{ConcLuston}

The foregoing canvass of constitutional problems requires a recapitulation. If the YCA Act were defended solely on the basis of the precedents derived from the minimum-maximum sentence statutes, it seems probable that it would survive attack on the ground that it is an invalid delegation to an administrative agency of the judicial power, of the governor's pardoning power or of the legislative power. There is a greater risk that the Act would be considered to impose a criminal punishment which, because indefinite in duration, is cruel and unusual, and not proportioned to the offender's crime. But these hazards might be circumvented if the Act were considered not to impose criminal punishment at all but, in the proceedings looking to the extension of control over at least the deficient, the disordered, or the abnormal offender, to be designed to impose controls similar to those civil restraints to which the juvenile, and especially the defective delinquent, offender may be subjected. The Act does not seem vulnerable to attack as a denial of equal protection of the laws and only the actuality, and not the potentiality, of administrative abuse would be likely to move a court to find a denial of procedural due process.

The major constitutional difficulties spring from the provisions for extended control; little basis for objection would be left if those provisions were excluded and control terminated at the age or time limits set in the YCA Act itself (or, where longer, at the limit prescribed in the criminal law for the particular offense committed). ${ }^{62}$ How important the extension of control provisions are is a matter which will have to be resolved in the various states that consider the measure. Those which take the bolder course of including these provisions may derive encouragement from the fact that most of the precedents considered in this article are old; many are expressions of the attitude of the judiciary nearly $5^{\circ}$ years ago, and must be read in that light. Psychology and psychiatry were still viewed as mystical or pseudo-sciences at that time; the belief that young offenders should be segregated from hardened criminals was relatively new and seldom honored in practice. These attitudes are an integral and inseparable part of those decisions. With evidence that youthful criminals

\footnotetext{
02 This is the limit prescribed in the California Youth Correction Authority Act, supra note $13, \$ 51780$ 1783. The court, upon petition by the Authority, may discharge, place on probation, or commit to the state penitentiary.
} 
require specialized treatment and that in many, if not most, instances punishment for whatever period will serve no useful purpose, the advocates of an absolutely indeterminate sentence may hope to persuade modern courts that the only sound basis for determining the length of time a youthful offender is to be kept under supervised control is an individualized study of that particular youth.

On the other hand, the proponents of the Act will meet with the insistence that there is still no science with means to determine the exact period of supervision necessary to effect the rehabilitation of every convicted criminal; that the liberty of a person should not be entrusted to so fallible a system; that there is practical need for protecting the offender from the possibilities of capricious and erroneous judgment; and that the solution to the problem for the time being lies in the existence of a maximum limit to confinement.

As was remarked earlier in this paper, in the conflict between these viewpoints, the penal philosophy of the legislators and judges, rather than the precedents in the books, is likely to be controlling. ${ }^{33}$

${ }^{03}$ The conflicting views are stated in the articles by John F. Perkins and James V. Bennett which precede this article. For another clash of opinion, see Hall, The Youth Correction Authority Act: Progress or Menace (May 1942) 28 A. B. A. J. 3I7; Lewis, The Youth Correction Authority Act: A Model, id. at 322 . 